\title{
Preparation for Future Learning: The Case of Rural Communities in Nigeria
}

\author{
Ismaila Temitayo Sanusi \\ School of Computing \\ University of Eastern Finland \\ Joensuu,Finland \\ ismails@uef.fi
}

\author{
Sunday Adewale Olaleye \\ Dept. of marketing, Management and \\ International Business \\ University of Oulu \\ Oulu, Finland \\ sunday.olaleye@oulu.fi
}

\author{
Adekunle Okunoye \\ School of Business \\ Xavier University \\ Cincinnati, USA \\ aokunoye@xavier.edu
}

\begin{abstract}
Preparation for future learning is crucial to economic development and poverty eradication because ignorance is the modern slavery of backwardness. Nigeria's population is increasing daily. With this growing population, there is a need for self-study, home study, Internet, or online study to meet the pressing worldwide demands for literacy training employing distance instruction. Internet use is linear in Nigeria, with forecasts of Internet users reaching 187.8 million in 2023. This study examines the preparation of rural communities in Nigeria for future learning; examines infrastructures and resources available that can facilitate future learning; and also explores the means and approaches to changes future learning systems through the lens of education learning theories. The theory of connectivism was employed. Based on the quantitative approach, this study used a questionnaire to collect data from rural residents of 2,377 samples and utilized SPSS v. 25 for descriptive statistics and regression analysis. Internet availability and affordability are central to future learning, especially in the angle of emerging technology intervention in future learning systems. This result shows that the location of the Internet user's residence and the frequency of Internet use depend on the Internet's cost. The excluded rural areas can leverage the Internet for flexible online programs and courses to reduce the alarming illiteracy rates.
\end{abstract}

\section{Keywords-future learning; rural; ICT; education; Nigeria}

\section{INTRODUCTION}

Preparation for future learning is crucial to economic development and poverty eradication because ignorance is the modern slavery of backwardness. Nigeria is populated, and the population is increasing daily. Presently theinstitutions, that is the Higher Education Institutions (HEI) in the country are not enough to cater for the present population, which is over 200 million [1] and with the projection that in 2050 Nigeria's population will be over 400 million and by so doing will overtake the United States as the world's third most inhabited country. As a result of this growing population, there will be a need for self-study, home study, Internet, or online study to meet the pressing worldwide demands for literacy training using distance instruction. New and emerging technologies will make it possible to meet the demands of the population.

Future learning is about technology, mobilization, approaches, and strategies to pursue personalized learning and open distance learning for all learners. USC Rossier, [2] states factors influencing what education may look like in the future: unprecedented global forces and unforeseen technologies and paradigm shifts in students' ways to learn, and teachers method to instruct. It stressed that it is vital to think about what we can do to prepare for the future to improve today's areas of need. The development of information technology and communication has dramatically influenced technology integration, particularly in the teaching and learning process [3]. USC Rossier [2] highlighted few areas schools should focus on evolving to create a bright future for education, and it includes a personalization, customization, innovative learning spaces, environments, and technology.

According to [4], almost all rural communities in the world have a problem with technological facilities and have not obtained any benefit from the advantages of using ICT. Hosseini et al., [5] stated that ICT challenges include the use of low-bandwidth, hardware shortages, lack of appropriate infrastructure, lack of software, telecommunications systems, and weak expertise in rural areas in using ICT. A recent study by [3] investigated rural students' acceptance toward using information, communication, and technology (ICT) for educational purposes. The study found that facilitating conditions, social influence, performance expectancy, and effort expectancy were significant determinants of behavioral intentions to use ICT for educational purposes. More studies are needed to assess the preparedness for future learning, which will guide the provision of recommendations to help authorities to prepare the appropriate technology equipment before new technology is introduced to rural learners. Recent studies examined the market dynamics perspective of public and private universities in Nigeria, focusing on the demand and supply of higher education [38] and social media use in Nigerian Universities as a strategic tool for communication [39]. These studies mentioned tools for future learning but not holistic.

Previous research offered a little basis for generalization to this study. There are a limited number of specific studies conducted concerning a social overview of communities and give predictive vision based on ICT facilities and resources focusing on rural society. Earlier studies such as [36] investigated the patterns in internet utilization among faculty and students in HEI, [37] also examined the information and learning needs of youth in a rural community. This study set out to examine the preparation of rural communities in Nigeria for kinds of learning settings that could be in the future. Also, what infrastructures and resources available and will be required. Finally, the study explored the means and approaches to learning changing in the future. Connectivism theory was employed as the theoretical framework to drive the study using a quantitative methodological approach in gathering the research data. The study is divided into five parts. The first section introduces the study. The second section synthesizes relevant literature, while section three explores the appropriate methodology for the study. Section 
four displays the data analysis, the result, and discussion, while the last section concludes on the findings followed by a limitation with future study alertness.

\section{THEORETICAL FRAMEWORK AND REVIEW OF LITERATURE}

This section presents the connectivism as the theoretical framework adopted for the study and review the relevant literature.

McLaughlin (2020) [17] stated four key ways education seems to change in the future. These are (i) connectedness, collaboration, and co-creation; (ii) anywhere, anytime learning; (iii) customization for a learner-first approach; (iv) putting testing to the test. Summarily, the formal classroom would be replaced by learning areas that allow individuals, small groups, or larger groups to collaborate face-to-face or virtually on learning projects. Technology will be a must in learning for future education for students to be equipped with the skills to cope in a world dependent on technology. Furthermore, the future will focus on combining student engagement in learning, inquiry-based approaches, curiosity, imagination, and design thinking. Also, assessments in the future will be evidencebased, using measures that allow learning plans to be drawn up and personalized. As such, students become partners or co-creators of their learning.

Connectivism is characterized as a reflection of our society that is changing rapidly [6]. Connectivism theory provides a useful lens through which teaching and learning using digital technologies can be better understood and managed [7]. The Connectivism theory idea was developed by Downes [8],[9],[10] precisely for digital age learning. Connectivism offers specific technological opportunities for the learner to be actively involved in presenting a body of knowledge [6]. It is one of the most prominent of the network learning theories that have been developed for elearning environments [7]. Additionally, it offers that diversity through various networks, helping the new generations collaborate to find solutions to an everincreasing number of questions.

In the application of connectivism, the primary pedagogical method took the form of massive open online courses (MOOCs) conceptualized by Siemens and Downes, [11] [12]. It was a vast network of connected people and resources that learners can access, design, and direct their learning [7]. Authors recognize connectivism's potential to provide a useful perspective as to how learning might occur in the digitally saturated, connected world [13],[14],[15]. Its relevance is to contribute to environments where control is shifting from the tutor to more autonomous learners. Connectivism is increasingly described as a theory in educational literature [7].

\section{Methodology}

This study employed a quantitative methodology approach. The study adopts survey research. Survey research was employed as it helps the study to assess the thoughts, opinions, and feelings of respondents and also a viable means of generalizing the sample to the population. The researchers select respondents for the study from the Nigerian rural population and administer a standardized questionnaire. Besides, this study utilized SPSS v.25 for descriptive statistics and regression analysis to analyze the thoughts, opinions, and feelings of the respondents.

\section{A. Respondent Characteristics}

The study presents the demographic characteristics in Table I. The respondents include more males $(70.4 \%)$ than females $(29.6 \%)$, with a $40.8 \%$ difference. The age of the respondents ranges from 26-35 (34.7\%), followed by 36-45 $(28.9 \%)$ and the least $>65(0.6 \%)$. While generation $\mathrm{Y}$ characterizes the highest age bracket in this study, the interesting point is that the age bracket cut across different age groups, which means that all age groups' perception was captured in the survey. The majority of the respondents are educated, and the most frequent education level is high school/diploma 1637 (68.9\%), follow with bachelor's degree $419(17.6 \%)$, and no formal education is just $55(2.5 \%)$. Most of the respondents are married (73.1\%), followed by singles $(23.8 \%)$, divorced $(1.8 \%)$, and widow/widower $(1.3 \%)$. We grouped occupation into eight classes, and the descriptive analysis revealed most of the respondents are self-employed 905 (38.1\%), farmers constitute 12.2\% (290), and the workers of private organizations 96 (4.0\%) represent the least of the respondents. The highest frequent income earners earned less than 18,000 Naira (36.9\%), and the lowest $(.5 \%)$ income earners earned above 500,000 Naira. The participants of this study lived in Osun State, but they came from different ethnic groups. Yoruba's have (94.7\%), Igbo (2.2\%), Hausa (1.4\%), and other tribes constitute $1.7 \%$ of the respondent. The Yoruba tribe dominates this study with the apparent reason that Osun State is a State where the Yoruba tribe resides. Most of the respondents reside in a small town (40.3\%), followed by rural community dwellers $(36.1 \%)$ and urban settlers $(23.6 \%)$. The respondents' age has the highest mean, followed by education, while gender has the lowest mean.

\section{TABLE I. DEMOGRAPHY CHARACTERISTICS}

\begin{tabular}{|c|c|c|c|}
\hline Variable & Classification & Frequency & Percentage $\%$ \\
\hline \multirow[t]{2}{*}{ Gender } & Male & 1674 & 70.4 \\
\hline & Female & 703 & 29.6 \\
\hline \multirow[t]{7}{*}{ Age } & Less than 18 & 55 & 2.3 \\
\hline & $18-25$ & 394 & 16.6 \\
\hline & $26-35$ & 824 & 34.7 \\
\hline & $36-45$ & 688 & 28.9 \\
\hline & $46-55$ & 253 & 10.6 \\
\hline & $56-65$ & 149 & 6.3 \\
\hline & 65 and above & 14 & .6 \\
\hline \multirow{6}{*}{ Education } & Primary & 188 & 7.9 \\
\hline & Secondary/Dip & 1637 & 68.9 \\
\hline & Bachelor's degree & 419 & 17.6 \\
\hline & Master's degree & 63 & 2.7 \\
\hline & Doctoral degree & 11 & .5 \\
\hline & No formal Edu. & 59 & 2.5 \\
\hline \multirow{4}{*}{$\begin{array}{c}\text { Marital } \\
\text { Status }\end{array}$} & Married & 1738 & 73.1 \\
\hline & Single & 565 & 23.8 \\
\hline & Divorced & 43 & 1.8 \\
\hline & Widow/Widower & 31 & 1.3 \\
\hline \multirow[t]{6}{*}{ Occupation } & Unemployed & 286 & 12.0 \\
\hline & Civil servant & 164 & 6.9 \\
\hline & Self-employed & 905 & 38.1 \\
\hline & Private org. & 96 & 4.0 \\
\hline & Student & 167 & 7.0 \\
\hline & Teaching & 118 & 5.0 \\
\hline
\end{tabular}




\begin{tabular}{|c|c|c|c|}
\hline Variable & Classification & Frequency & Percentage $\%$ \\
\hline & Farmer & 290 & 12.2 \\
\hline & Trader & 279 & 11.7 \\
\hline \multirow[t]{7}{*}{ Income } & Less than 18,000 & 877 & 36.9 \\
\hline & $¥ 18,100-30,000$ & 654 & 27.5 \\
\hline & $¥ 30,100-50,000$ & 403 & 17.0 \\
\hline & $\$ 50,100-100,000$ & 253 & 10.6 \\
\hline & ₹100,001-250,000 & 129 & 5.4 \\
\hline & N250,001-500,000 & 45 & 1.9 \\
\hline & Above $¥ 500,000$ & 13 & .5 \\
\hline \multirow[t]{4}{*}{ Ethnic } & Yoruba & 2252 & 94.7 \\
\hline & Igbo & 52 & 2.2 \\
\hline & Hausa & 33 & 1.4 \\
\hline & Others & 40 & 1.7 \\
\hline \multirow{3}{*}{$\begin{array}{c}\text { Type of } \\
\text { community }\end{array}$} & Rural community & 857 & 36.1 \\
\hline & Small city & 958 & 40.3 \\
\hline & Urban community & 562 & 23.6 \\
\hline
\end{tabular}

TABLE II. DEMOGRAPHY MEAN AND STD. DEVIATION

\begin{tabular}{|l|c|c|c|}
\hline & GENDER & AGE & EDUCATION \\
\hline $\mathbf{N}$ & 2377 & 2377 & 2377 \\
\hline $\mathbf{M}$ & .456 & 1.175 & .855 \\
\hline SD & 1.30 & 3.50 & 2.26 \\
\hline
\end{tabular}

\section{B. Sample and Data Collection}

The survey queried the residents of the State of Osun across age groups and socio-economic backgrounds. The study collects primary data across the state, of 30 local government areas (LGA). The LGAs comprise 332 electoral wards, and the wards divide into 3,010 polling units where eligible voters cast their votes. The 3010 polling units in the state were purposively selected, and a person represents each of the polling units as respondents. The survey was conducted using a hardcopy questionnaire. Three thousand two hundred twenty-six $(3,226)$ citizens of the state were surveyed representing each polling unit and electoral wards. The researchers received 2,736 (84.81\%) filled-out questionnaires, out of which 2,377 (73.71\%) were suitable for the analyses. The questionnaire used was adapted from [16].

\section{Instrument}

In this study, the preparation of rural communities in Nigeria for future learning and infrastructures as resources available and will be required were investigated. Paperbased questionnaires were administered to residents of the communities to gather data on demographic characteristics, ICT tools use, and Internet access. Specifically, to understand the variables mentioned above, items were adapted from [16], and participants were presented with close-ended questions employing 5-point scales response mode for some of the items.

TABLE III. ITEMS MEANS AND STANDARD DEVIATION

\begin{tabular}{|l|l|l|c|c|c|c|c|}
\hline & $@$ TO & PB & IA & SMAO & SOMA & LO & LB \\
\hline $\mathbf{N}$ & 2377 & 2377 & 2377 & 2377 & 2377 & 2377 & 2377 \\
\hline $\mathbf{M}$ & 1.17 & 3.01 & 1.30 & 1.43 & 1.81 & 1.82 & 4.21 \\
\hline SD & .470 & 1.543 & .456 & 1.114 & 1.008 & .380 & 1.381 \\
\hline
\end{tabular}

TABLE IV. ITEMS MEANS AND STANDARD DEVIATION

\begin{tabular}{|l|l|c|c|c|c|}
\hline & ATI & IISP & IATC & CIA & NIA \\
\hline $\mathbf{N}$ & 2377 & 2377 & 2377 & 2377 & 2377 \\
\hline $\mathbf{M}$ & 1.37 & 2.59 & 3.49 & 3.31 & 2.45 \\
\hline SD & .483 & 1.769 & 1.159 & 1.172 & 1.142 \\
\hline
\end{tabular}

Note: TABLE V contains the abbreviations and corresponding items meaning.

\section{TABLE V. ITEMS AND CORRESPONDING ABBREVIATIONS}

\begin{tabular}{|l|l|}
\hline & Items \\
\hline$@$ TO & Do you own a mobile phone or tablet? \\
\hline PB & What brand of phone or tablet do you use? \\
\hline IA & Does your phone have internet access? \\
\hline SMAO & $\begin{array}{l}\text { Which of the social media account do you } \\
\text { operate? }\end{array}$ \\
\hline SOMA & $\begin{array}{l}\text { Which of the following social media App do } \\
\text { you use most? }\end{array}$ \\
\hline LO & Do you own a laptop? \\
\hline LB & What brand of laptop do you use? \\
\hline ATI & Do you have access to internet? \\
\hline IISP & $\begin{array}{l}\text { Which service provider do you use for } \\
\text { internet? }\end{array}$ \\
\hline IATC & I consider internet access too costly \\
\hline CIA & $\begin{array}{l}\text { I browse once in a while due to the cost of } \\
\text { internet access }\end{array}$ \\
\hline NIA & There is no internet access in my area \\
\hline
\end{tabular}

Table III and IV contains the items mean and standard deviation. Of all the items, the respondents' laptop brand has the highest mean while ownership of the mobile phone has the least mean.

\section{RESULT AND DISCUSSION}

This section presents the results of the data analysis and further discusses them. For instance, Figures 1-9 revealed ICT usage across communities by the sampled respondents.

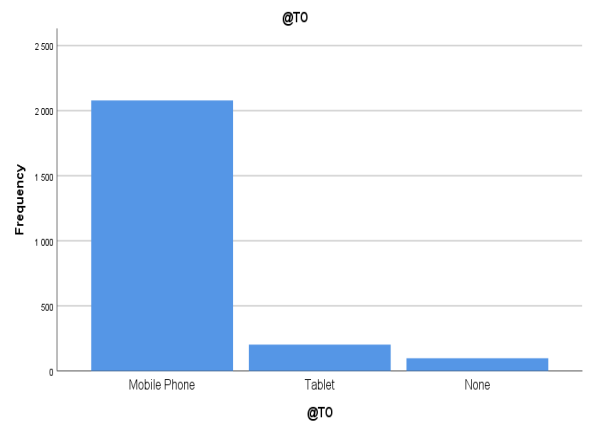

Fig. 1: Mobile phone ownership

Fig. 1 shows that $87.4 \%$ of the respondents own a mobile phone of different brands, $8.5 \%$ owns tablet device, while only $4.1 \%$ did not own a mobile phone of any kind.

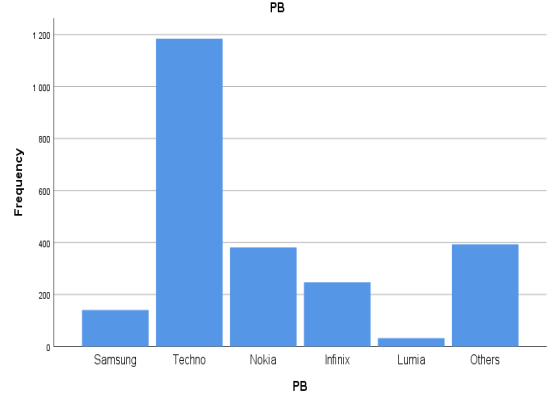

Fig. 2: Phone brand 
In Fig. 2. most of the sampled respondents (49.8\%) uses Techno brand of mobile or tablet device. Nokia (16.0\%) is the next most used brand of the mobile device among the respondents, followed by Infinix (10.4\%) and Samsung $(5.9 \%)$, while Lumia $(1.3 \%)$ is the least used among the brands. Other brands aside, those itemized accounts for $16.5 \%$.

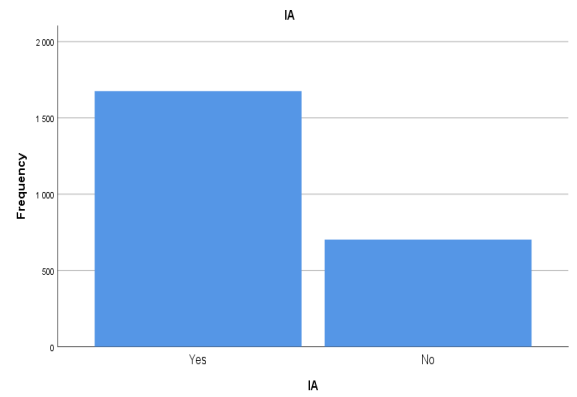

Fig. 3: Phone Internet Access

Fig. 3 shows that $70.4 \%$ of respondents have access to the internet through their phones, while $29.5 \%$ could not access the Internet.

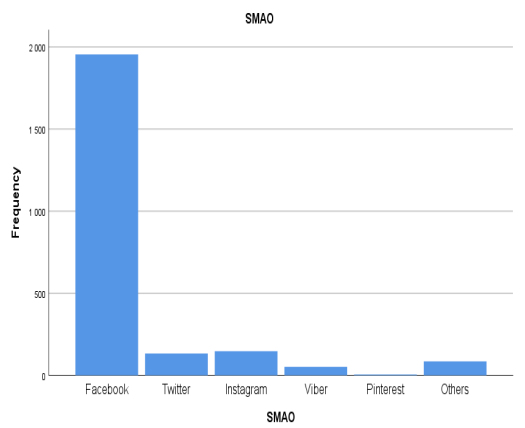

Fig. 4: Social media account

Fig. 4 reveals the social media account the respondents operate. Most of all, the respondents (82.2\%) have a Facebook account. $6.2 \%$ operate on Instagram, followed closely twitter users (5.6\%). Viber accounts for $2.2 \%$, while Pinterest has the list subscribers with $.2 \%$. Other social media account apart from earlier listed accounts for 3.6\%.

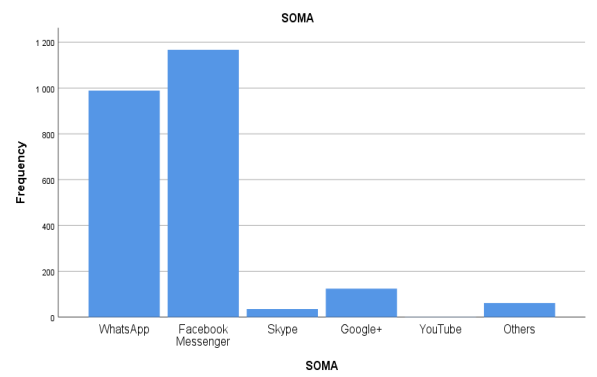

Fig. 5: Social media App

Fig. 5 shows the most used social media App among the respondents. Facebook Messenger (49.1\%) tops the most used app, followed by WhatsApp at $41.6 \%$. Skype is the least of the Apps used among the respondents at 1.5\%, although other apps are used apart from those highlighted earlier.

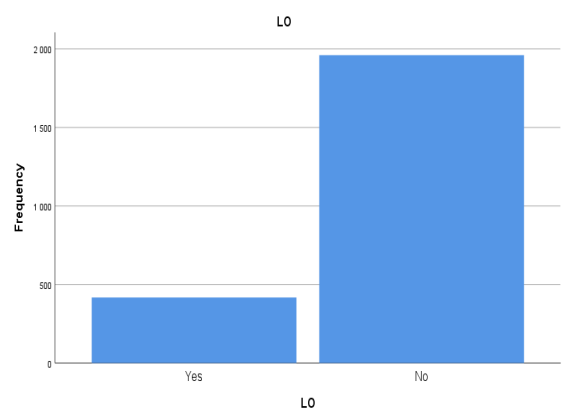

Fig. 6: Laptop ownership

Fig. 6 reveals that most of the respondents $(82.5 \%)$ do not own laptops, while only $17.5 \%$ represent the individuals who own a laptop.

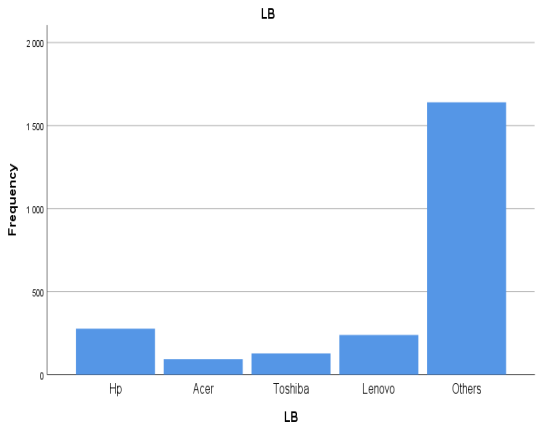

Fig. 7: Laptop brand

Fig. 7 shows the brand of a laptop owned by the respondents. They used various laptop brands such as apple, dell, Samsung, among others. Hp is however the most used brand among the respondents.

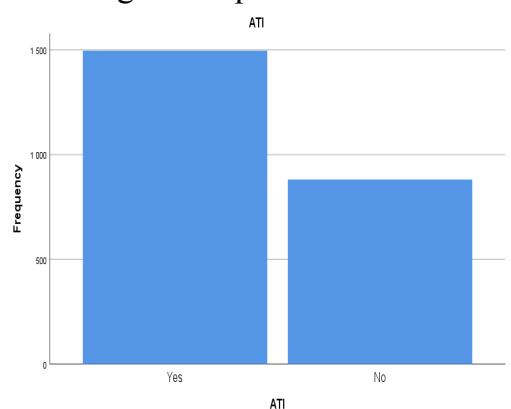

Fig. 8: Laptop access to Internet

Fig. 8 shows the respondents that have access to the Internet through their laptop. $62.9 \%$ of the respondents can access the Internet through their laptops, while only 37.1 do not access the Internet.

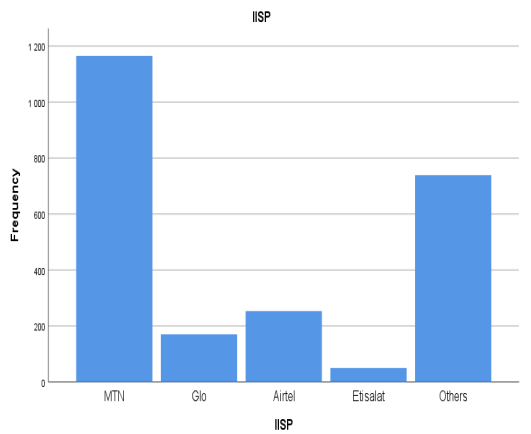

Fig. 9: Internet service provider 
Fig. 9 reveals the service provider used for the Internet among the respondents. The majority of the respondents (49.0\%) use MTN to access the Internet; $10.6 \%$ use the Airtel network, followed by Glo at $7.2 \%$. The Etisalat subscriber has the least representation with $2.1 \%$.

TABLE VI. REGRESSION ANALYSIS RESULT

\begin{tabular}{|c|c|c|c|c|c|c|c|c|c|}
\hline $\begin{array}{c}\text { Model } \\
\text { (IATC) }\end{array}$ & $\boldsymbol{\beta}$ & SE & St. $\boldsymbol{\beta}$ & $\mathbf{t}$ & $\mathbf{R}$ & $\mathbf{R}^{2}$ & $\begin{array}{c}\text { Adj. } \\
\mathbf{R}^{2}\end{array}$ & SE & F \\
\hline Constant & .413 & .023 & & 18.24 & $\begin{array}{l}.94 \\
9\end{array}$ & $\begin{array}{l}.90 \\
0\end{array}$ & .900 & .367 & $\begin{array}{c}10690 . \\
3\end{array}$ \\
\hline CIA & .836 & .011 & .85 & 75.68 & & & & & \\
\hline NIA & .125 & .011 & .12 & 11.06 & & & & & \\
\hline
\end{tabular}

${ }^{* * *} \leq 0.001, * * 0.001<\mathrm{p} \leq 0.01,{ }^{*} 0.01<\mathrm{p} \leq 0.05$
Dependent variable: IATC - Internet Access Too Costly, Predictors: CIA: Cost of Internet Access, NIA: No Interne Access, $\beta$ : Beta, SE: Standard Error, SE: Standard error, St..: Standardized beta, SE: Standard error, T: T-test, $\mathrm{R}^{2}$ : Coefficient of determination, $\mathrm{F}$ : F-tes

\section{Regression Model}

The authors run linear regression analysis for a model that has CIA and NIA as predictors against IATC. The predictor variables in the model were significant, CIA $\rightarrow$ IATC $(\beta=0.85, \mathrm{t}=75.68, \mathrm{P}-$ Value $=<.001), \mathrm{NIA} \rightarrow$ IATC $(\beta=0.12, \mathrm{t}=11.06$, P-Value $=<.001)$.

It can be deduced based on the study's findings that even though the infrastructure and resources are inadequate, some preparedness for the kinds of learning that will occur in the future is evident across the communities. For instance, almost all the respondents own a mobile phone or tablet device. Since most people already own a mobile device, learning through the devices is possible, as the studies of [18] [19] attests that people own and use various mobile devices to learn nowadays. However, even though the respondents' devices' brands are reported, the devices' functionalities are unknown. So, we can never tell if their phones or tablets' features can enable learning-features such as compatibility with internet connections and download of apps, among others. Considering the communities' socio-economic status, the may possess basic mobile phone since it is affordable compared to smartphones and tablets. The internet's availability for use on the respondents' devices ensures connectivity. By so doing, they will have access to internet resources. With the Internet, download, and installation of mobile apps, files sharing, and information irrespective of the distance and communicating via social media platforms is possible.

Our study further revealed that a very high percentage of the respondents operate social media account with Facebook emerging as the most used social network. Based on the data from Statista [20], as of the second quarter of 2020, Facebook is the biggest social network worldwide, with over 2.7 billion monthly active users. Studies have shown positive impacts of the Facebook app as a potential tool for the teaching and learning process [21] [22] [23] [24]. According to our findings, the ranking as the most used SNS indicates that Facebook has great potential to be used as a tool for teaching and learning. Facebook's popularity worldwide could also be considered a potential to be integrated into teaching and learning as it provides its users with the opportunity to interact with people of different mother tongues and countries of origin [24]. Thus, Facebook will be a useful tool for learning in the future. Our findings further show that WhatsApp is a widely used app among the respondents. This insight is an indication that WhatsApp can be used to target the population for teaching and learning. Several studies have been carried out on the use of WhatsApp platforms in learning. Such studies include [25], which found Whatsapp effectiveness in teaching and learning. Agbo et al. [26] also examined WhatsApp by computer science students for learning computing education, which shows that its use contributes positively to students' learning achievement. Wargadinata et al. [27] show that the WhatsApp group is effective for learning because it is easy, simple, with a small data quota package requirement. While other SNS are utilized across the communities, such as Instagram and Twitter, empirical evidence attests to the use and effectiveness of social networking sites in the teaching and learning process.

Additionally, only $17.5 \%$ of the sampled respondents own a laptop. This statistic is relatively low compared to the level at which they own a mobile phone or tablet device. The low socio-economic characteristic of the communities accounts for this low level of ownership. While evidence exists that teaching and learning are possible through phones and tablet devices [18] [19], laptops can be more useful for learning. For instance, scholars state that mobile phone screens are too small to provide a comfortable learning environment [28] [29]. A recent study by [30] explores how smartphones vs. laptops' use influences students' engagement, behaviour, and experience watching educational videos in a collaborative classroom. The results indicate that laptops' use has provided better results in student engagement with the videos, their collaborative behaviour, and satisfaction with the device. Our findings suggest that access to a laptop or PC will make learning more accessible in the future across communities. This study also reveals that internet facilities are available across the sampled communities through service providers such as MTN, Airtel, and Glo. However, access to the Internet comes with a cost, which hinders exploring the opportunities that come with Internet resources by the community members. This cost implication reduces drastically the rate at which they browse the net.

The regression analysis result shows that internet availability and affordability are central to future learning, especially in emerging technology intervention in future learning systems. This direction indicates that the location of the internet user's residence and Internet use frequency depend on the Internet's cost. The excluded rural areas can leverage the Internet for flexible online programs and courses to reduce the alarming illiteracy rates. Internet connectivity has allowed for distance and online learning, regardless of location and level of development [31]. Meeker, [32] also opine that the web can help provide costeffective access to educational materials, increase literacy and engagement of people living in poverty. The Internet has a vast potential for inclusive growth and socio-economic development, including educational opportunities expansion [33]. According to the ITU statistics [34], Africa is the fastest-growing region in the world in terms of Internet penetration, with the growth mainly driven by a vast expansion in mobile-broadband. The potential of the 
Internet is, however, still largely unexplored in Africa [35]. Guerriero [35] states that the Internet's price is very critical for policies aimed at increasing Internet connectivity in developing countries. The access to the Internet and its use is increasing, which is expected to continue to increase over the next few years, in many Sub-Saharan African economies [35].

\section{CONCLUSION}

This study aimed to examine the preparation of rural communities in Nigeria for future learning, examining infrastructures and resources available that can facilitate future learning and also explores the means and approaches to changes future learning systems through the lens of education learning theories-using SPSS, descriptive, and linear regression statistical technique. Internet use is linear in Nigeria, with forecasts of Internet users reaching 187.8 million in 2023. This statistic is a pointer that e-learning is possible with the provision of necessary resources and facilities. The findings reveal that the respondents use ICT tools, and most of the respondents have access to the Internet. Though Internet access is too costly, and due to the high cost, the respondents browse once in a while and have limited Internet access. Internet availability and affordability are central to future learning, especially in the angle of emerging technology intervention in future learning systems. The study shows that the location of the Internet user's residence and the frequency of Internet use depend on the Internet's cost. The excluded rural areas can leverage the Internet for flexible online programs and courses to reduce the alarming illiteracy rates.

\section{Study Limitation and Future Study}

Examining future learning across different climes, locality, and communities are necessary to prepare for the future demands of distance and personalized instruction. The study covered the communities in a state of the country with thirty-six states. Future studies should endeavour to carry out an interstates study on future learning preparation in Nigeria for comparison. Additionally, the present study only focuses on rural communities that are not representing all types of communities. Due to this limitation, the future researcher should conduct a study of urban communities in developing countries. Consequently, a comparative study with a focus on countries and different community types should be explored. This study will give insight into the preparedness rate for learning in the future, which emerging technologies will provide.

\section{REFERENCES}

[1] Worldometers, "Nigeria Population", Retrieved December 7, 2019 from https://www.worldometers.info/world-population/nigeriapopulation/

[2] USC Rossier, "What Will Education Look Like in 20 Years?", 2014 Retrieved on 24-07-2020 from https://rossieronline.usc.edu/blog/education-20-years/

[3] S.H. Halili and H. Sulaiman, "Factors influencing the rural students' acceptance of using ICT for educational purposes", Kasetsart Journal of Social Sciences xxx 1- 6, 2018.

[4] A. Hasan, S. Murat, and E. Kemal, "Challenge of rural people to reduce digital divide in globalized world: Theory and practice", Government Information Quarterly, 24, 60-70. 2007
[5] S. J. F. Hosseini, M. Niknami, and M. Chizari, "To determine the challenges in the application of ICTs by the agricultural extension service in Iran. Journal of Agricultural Extension and Rural Development, 1(1), 292-299, 2009.

[6] Duke, B., Harper, G., \& Johnston, M. (2013). Connectivism as a digital age learning theory. The International HETL Review, 2013(Special Issue), 4-13.

[7] Goldie, J. G. S. (2016). Connectivism: A knowledge learning theory for the digital age?. Medical teacher, 38(10), 1064-1069.

[8] Downes S. 2005. An introduction to connective knowledge. Stephen's Web; [cited 2015 Aug]. Available from: http://www.downes.ca/cgibib/page.cgi?post 1/433034.

[9] Downes S. 2006. Learning networks and connective knowledge; [cited $2015 \mathrm{Aug}$ ]. Available from: http://itforum.coe.uga.edu/paper92/ paper92.htlm.

[10] Downes S. 2012. Connectivism and connective knowledge. Essays on meaning and learning networks; [cited 2015 Aug]. Available from: http://www.downes.ca/files/books/Connective_Knowledge19May201 2.pdf.

[11] Downes S. 2015. e-learning symposium plenary. Glasgow: AMEE.

[12] Siemens G, Downes S. 2008, 2009. Connectivism and connected knowledge; [cited 2015 Aug]. Available from: http://tc.umanitoba.ca/ connectivism

[13] Bell F. 2011. Connectivism: its place in theory-informed research and innovation in technology-enabled learning. Int Rev Res Open Dis Learn. 12:98-118.

[14] Lange M. 2012. Talk: connectivism; [cited 2015 Aug]. Available from: http://en.wikipedia.org/wiki/Talk:Connectivism

[15] Clara M, Barbera E. 2013. Three problems with the connectivist conception of learning. J Comput Assist Learn. 30:197-206.

[16] Michigan State University Institute for Public Policy and Social Research, "State of the State Survey 69" [Data file and code book]. Retrieved from http://ippsr.msu.edu/soss/" (2014).

[17] McLaughlin, T. (2020). The future of learning and teaching: Big changes ahead for education. Retrieved on 24-07-2020 from https://www.rmit.edu.au/study-with-us/education/discovereducation/the-future-of-learning-and-teaching-big-changes-ahead-foreducation

[18] I.T. Sanusi, S.S. Oyelere, S.A. Olaleye, J. Suhonen and A.O. Otunla, "Exploring Students and Teachers Activities, Experiences and Impact of Opón İmò Mobile Learning Device", IEEE Africon 2017 Proceedings, pp. $788-793,2017$.

[19] S.S. Oyelere, J. Suhonen \& E. Sutinen, "M-Learning: A new paradigm of learning ICT in Nigeria," International Journal of Interactive Mobile Technologies (iJIM), vol. 10, no. 1, pp. 35-44, 2016.

[20] Statista, "Number of monthly active Facebook users worldwide as of 2nd quarter 2020(in millions)", Retrieved September 13, 2020, from https://www.statista.com/statistics/264810/number-of-monthly-activefacebook-users-worldwide/

[21] R.S. Rodliyah, "Using a Facebook Closed Group to Improve EFL Students' Writing" TEFLIN, vol. 27, no. 1, pp. 82-100, 2016. https://doi.org/http://dx.doi.org/10.15639/teflinjournal. v27i1/82-100

[22] D. Khusnita, "The Use of Facebook to Improve Students' Skill and Increase", In English Language and Literature International Conference (ELLiC) Proceedings. Semarang: Universitas Negeri Semarang, 2017.

[23] R. Fithriani, "Discrimination behind NEST and NNEST Dichotomy in ELT Professionalism" In 1st Annual International Conference on Language and Literature, KnE Social Sciences, pp. 741-755, 2018. DOI 10.18502/kss.v3i4.1982

[24] R. Fithriani, U. Dewi, S.H. Daulay, M. Salmiah, and W. Fransiska, “ Using Facebook in EFL writing class: Its effectiveness from students' perspective", KnE Social Sciences, pp. 634-645, 2019.

[25] A. Oriji, and F. Anikpo, "Social Media in Teaching-Learning Process: Investigation of the Use of Whatsapp in Teaching and Learning in University of Port Harcourt", European Scientific Journal, vol. 15, no. 4, $1857-7881,2019$.

[26] F.J. Agbo, O. Olawumi, S.A. Olaleye, K. Sunday, O.S. Balogun, E.A. Kolog, D.D. Atsa'am, I.T. Sanusi, F. Adusei-Mensah, A. Adegbite and F.W. Ipeayeda, "Investigating Students' Perception on the Use of Social Media Platform for Computing Education", Journal of Information Systems in Education (In press), 2020. 
[27] W. Wargadinata, I. Maimunah, E. Dewi, and Z. Rofiq, " Student's Responses on Learning in the Early COVID-19 Pandemic" Tadris: Jurnal Keguruan dan Ilmu Tarbiyah, vol. 5, no. 1, 141-153, 2020.

[28] M. Wang and R. Shen, "Message Design for Mobile Learning: Learning Theories, Human Cognition and Design Principles", British Journal of Educational Technology vol. 43, no. 4, pp. 561-575, 2012 doi:10.1111/j.1467-8535.2011.01214.x.

[29] A. Alamri, G. Muhammad, A. A. Al Elaiwi, K. N. Al-Mutib, and M. S. Hossain. "Media Content Adaptation Framework for Technology Enhanced Mobile e-learning." Journal of Universal Computer Science vol. 20, no.15, pp. 2016-2023, 2014.

[30] L. Albó, D. Hernández-Leo and V. Moreno Oliver, "Smartphones or laptops in the collaborative classroom? A study of video-based learning in higher education", Behaviour \& Information Technology, vol. 38, no. 6, pp. 637-649, 2019.

[31] Broadband Commission. (2014). The State of Broadband 2014: Broadband for all. Geneva.

[32] M. Meeker, "Internet Trends 2014 - Code Conference", Kleiner Perkins Caufield Byers, 2014

[33] Dalberg, "Impact of the Internet in Africa. Establishing conditions for success and catalysing inclusing growth in Ghana, Kenya, Nigeria and Senegal" 2013
[34] ITU, "ICT Statistics", Geneva: International Telecommunication Union, 2014.

[35] M. Guerriero, "The impact of Internet connectivity on economic development in Sub-Saharan Africa. EPS Peaks, pp. 103-1172, 2015.

[36] I. Poda, J.W. Murry Jr, J. and M.T. Miller, "Internet Use in the Developing World: A Case Study of an African University", International Education Journal, vol. 7, no. 3, pp. 235244, 2006.

[37] W.E. Nwagwu, "Information and learning needs of youth in a rural community in Nigeria", World Journal of Science, Technology and Sustainable Development, vol. 7 no. 1, pp. 4960, 2010. https://doi.org/10.1108/20425945201000004.

[38] Olaleye, Sunday, Ukpadi, Dandison and Mogaji, Emmanuel (2020) Public vs private universities in Nigeria: market dynamics perspective. In: Mogaji, Emmanuel, Maringe, Felix and Hinson, Robert, (eds.) Understanding the Higher Education Market in Africa. Routledge Studies in Marketing . Routledge, Oxfordshire, UK. ISBN 978-0367344382.

[39] Olaleye, Sunday; Ukpabi, Dandison; Mogaji Emmanuel (2020). Social Media for Universities' Strategic Communication : How Nigerian universities use Facebook. In Mogaji, Emmanuel; Maringe, Felix Maringe, Ebo Hinson, Robert (Eds.) Strategic Marketing of Higher Education in Africa, Routledge Studies in Marketing. Abingdon: Routledge, Chapter 8. DOI: 10.4324/9780429320934-9. 